Trans acting regulation of $\beta$ globin gene expression in erythroleukemia (K562) cells

Katherine Young, Maryann Donovan-Peluso, Rosemarie Cubbon and Arthur Bank*

Columbia University, College of Physicians and Surgeons, Department of Medicine, and Department of Human Genetics and Development, New York, USA

ABSTRACT :

K562 cells are induced by hemin to produce $r$ and $\varepsilon$ globin but not $B$ globin, although the $B$ globin gene is intact, and when isolated is expressed in a transient expression assay $(1,2)$. We have previously shown that an $\varepsilon$ globin gene transferred into $\mathrm{K} 562$ cells is expressed and inducible ( 3$)_{\text {s }}$ In this paper, we report the stable transfer of a sickle or ${ }_{B} S$ globin gene into $\mathrm{K} 562$ cells. Thirty-six different transformed lines were tested; 24 of 36 lines contained an intact $B S$ globin gene. However, using $S 1$ nuclease, Dot blot, and Northern blotting analyses, none of these lines showed $B$ globin mRNA expression. These results indicate that trans acting factors are responsible for the lack of expression of the globin gene in K562 cells.

\title{
INTRODUCTION :
}

K562 cells are a human erythroid cell line derived from a patient with chronic myelogenous leukemia (4). These cells respond to induction by producing fetal and embryonic globins, but no detectable adult globins $(5,6)$. This is in contrast to mouse erythroleukemia cells (MELC) which produce adult but not embryonic or fetal globins after induction (7). The amounts of the different globins in $\mathrm{K} 562$ cells are reflected in the relative levels of the respective globin mRNAs, with $B$ globin mRNA being undetectable (7-9). One strain of K562, called K562 Bos, contains very low amounts of $\varepsilon$ globin mRNA and protein. The low level of $\varepsilon$ globin mRNA in $\mathrm{K} 562$ Bos and the absence of $B$ globin mRNA in all K562 strains is due to the lack of transcription of these genes $(9,10)$. The absence of $B$ globin gene transcription is not due to a gene deletion $(2,5)$; in fact, a K562 B globin gene is expressed when isolated and tested in a transient expression assay $(1,2)$. Stable gene transfer experiments have been carried out to determine whether this gene inactivation is a cis or a trans 
effect. We have previously shown that exogenous $\varepsilon$ globin genes are expressed when added to $\mathrm{K} 562$ Bos cells (3). In this paper, we show that the silencing of the $B$ globin gene in $\mathrm{K} 562$ cells is due to a trans acting factor: in all the transformed lines, which have integrated the entire $B^{S}$ globin gene, no $B$ globin mRNA accumulates.

The experimental approach in this work was to stably transform $\mathrm{K} 562$ cells with a psv2neo-derived plasmid vector containing the ${ }_{B} S$ globin gene. A $\beta^{S}$ globin gene was used so the expression of the exogenous gene if it occurred could be distinguished from that of the endogenous gene. Transformed cells were selected with $\mathrm{G} 418$ and tested for the presence of $\beta^{S}$ globin mRNA after hemin induction by RNA dot blots and $\mathrm{Sl}$ nuclease analysis. The lines were then tested for the presence of an intact ${ }_{B} S$ globin gene. The ${ }^{S} S$ globin insert used in this experiment is the 4.4 kilobase (kb) Pst I fragment which contains the entire $B^{S}$ globin gene with $2.2 \mathrm{~kb}$ of $5^{\circ}$ flanking and $0.5 \mathrm{~kb}$ of 3' flanking sequences. This same $\beta$ globin gene fragment is inducible after stable gene transfer in 14 of 16 transformed MELC lines (11). Other $B$ globin fragments containing $\backsim 2 \mathrm{~kb}$ of 5 ' flanking sequence are also inducible in MELC after stable gene transfer $(12,13)$. Therefore, our results suggest that the silencing of the $\beta$ globin gene in $\mathrm{K} 562$ cells is due to a trans acting factor and is presumably occurring because these cells are in an embryonic/fetal, not adult, stage.

\section{MATERIALS AND METHODS:}

Techniques are as previously described (3). Semi-attached cells selected from the strain K562-2 (9) were used for transformation. After the G418-resistant colonies were picked, the cells were grown in suspension. The vector $p s v 2 n e o-\beta$ was made using psv2neo (14), and a plasmid containing a $B$ globin gene, a gift from B. Wallace. The $4.4 \mathrm{~kb}$ Pst I fragment containing the ${ }_{B} S$ globin gene was ligated into the Pst $I$ site in the ampicillin resistance gene of psv2neo (Figure 1). In the transfections, the DNA calcium phosphate precipitates contained 20 $\mu \mathrm{g}$ uncut $\mathrm{pSV} 2 \mathrm{neo- \beta} \mathrm{S}$, and $10 \mu \mathrm{g}$ salmon sperm DNA/10 $\mathrm{cm}$ plate seeded 


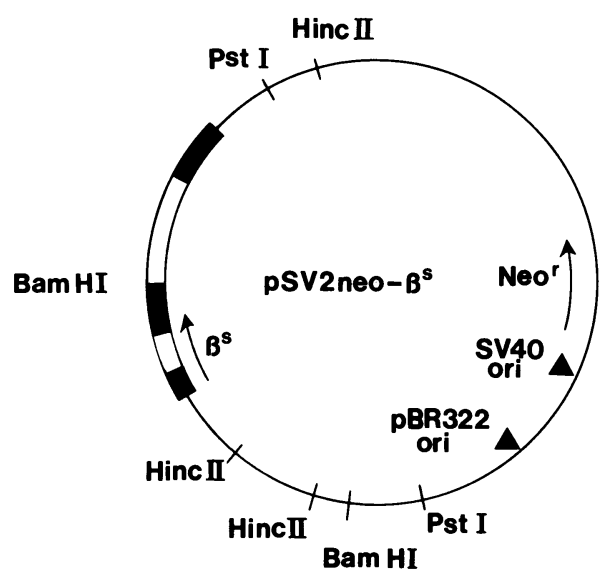

Figure 1:

Plasmid used in transfusions:

psv2neo-B is $10.0 \mathrm{~kb}$ in total size, and contains the Neor gene described (14), pBR 322 sequences, and $4.4 \mathrm{~kb}$ of cellular DNA sequences containing the structural $B$ gene (rectangular area). The exons of the ${ }_{B}$ gene are in black, and the introns are the clear areas. The cellular DNA insert extends from the Pst sites $5^{\prime}$ and $3^{\prime}$ to the gene.

with $5 \times 10^{5}$ cells. DNA and RNA were prepared as described previously (3).

Radioactive probe was washed off the RNA dot blots by the method given by Pall Ultrafine Filtration Corporation (Glenn Cove, New York) for hybridization of Biodyne A membranes. The filters were placed in $100 \mathrm{ml}$ of $10 \mathrm{mM}$ Na Phosphate, $\mathrm{pH} 6.5,508(\mathrm{v} / \mathrm{v})$ formamide/100 $\mathrm{cm}^{2}$ filters. After incubation for one hour at $65^{\circ} \mathrm{C}$, the filters were rinsed in $250 \mathrm{ml}$ of $2 \mathrm{X} \mathrm{SSC}, 0.18 \mathrm{SDS} / 100 \mathrm{~cm}^{2}$ filters for 15 minutes at room temperature with shaking. The filters were then prehybridized and hybridized again.

\section{RESULTS :}

Transformation efficiency:

Fifty-five G418-resistant colonies were picked, each from a separate plate, and grown into mass culture for analysis. Because these cells are only semi-attached, it is not possible to calculate transformation efficiencies by counting the colonies on each plate. After three weeks, 60 plates, each seeded with $5 \mathrm{X}$ $10^{5}$ cells, contained G4l8-resistant colonies - selection indicating an efficiency $>2 \times 10^{-6}$. 


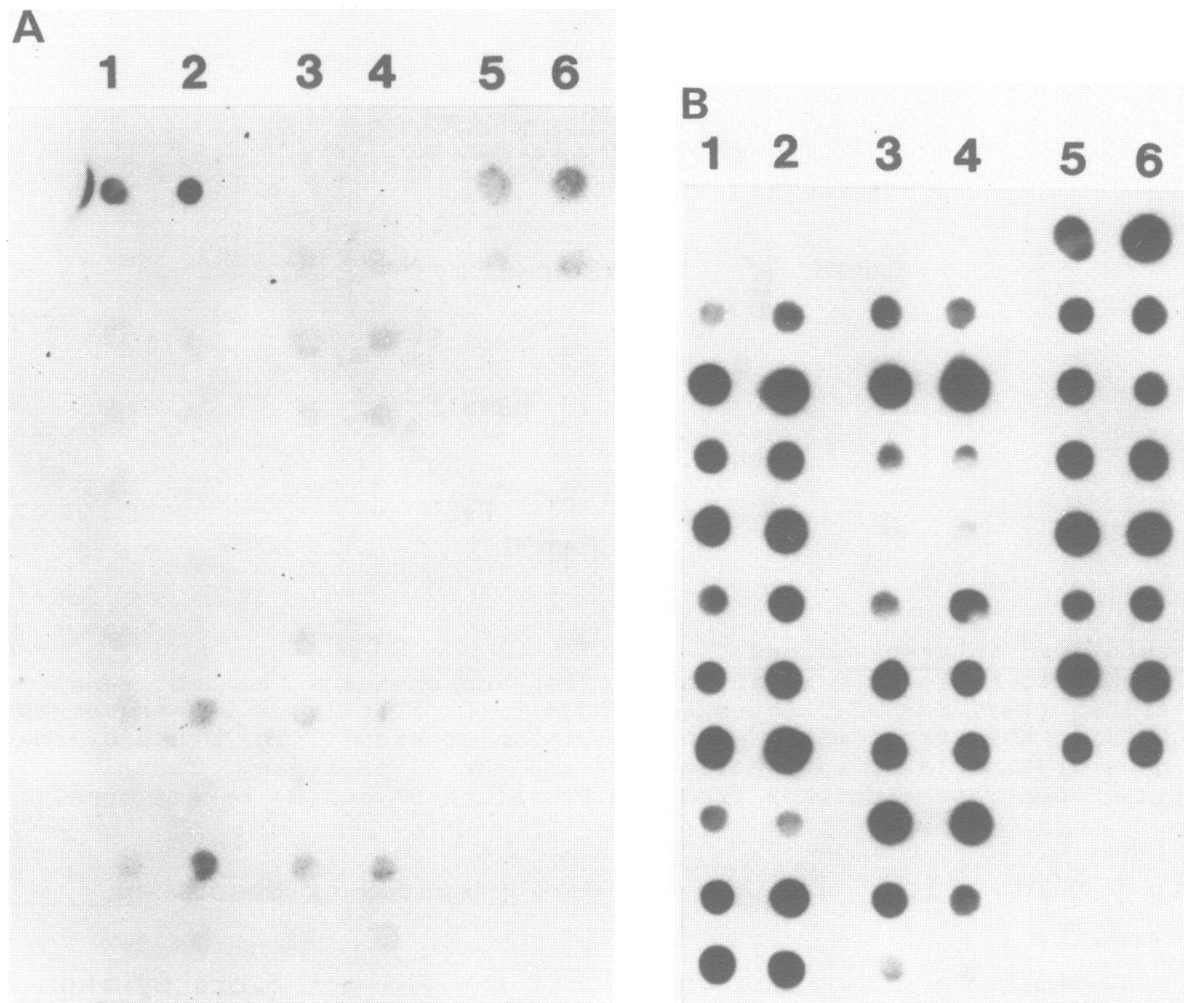

Figure 2:

DOt blot assay of K562 RNA:

Total RNA was dotted onto Biodyne A nylon, and probed with either the $1.8 \mathrm{~kb}$ Bam HI $B$ globin gene fragment (A), or the $0.7 \mathrm{~kb} B a m$ HI $\varepsilon$ globin gene fragment (B). Probes were nick translated to a specific activity of $5 \times 10^{\circ} \mathrm{cpm} / \mu \mathrm{g}$. The top row contains the controls - 1: 5 ng reticulocyte RNA; 2: 10 ng reticulocyte RNA; 3: blank; 4: blank;

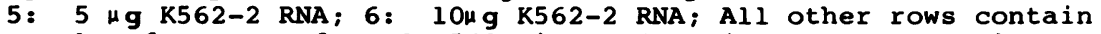
samples from transformed K562 lines: $5 \mathrm{\mu g}$ (columns $1,3,5$ ) and $10 \mathrm{\mu g}$ (columns 2, 4, 6) of each sample were applied.

Screening for $\underline{\underline{B}}$ globin gene expression:

Because of the large number of G418-resistant lines obtained, RNA dot blots were done to screen for expression of the $B \mathrm{~S}$ globin gene. RNA was prepared from cells which had been treated with 20 $\mu M$ hemin for 4 days, and 5 and $10 \mu g$ total RNA were dotted onto nitrocellulose filters. Ten ng reticulocyte RNA were used as a positive control, and RNA from nontransformed $\mathrm{K} 562$ was used as the 


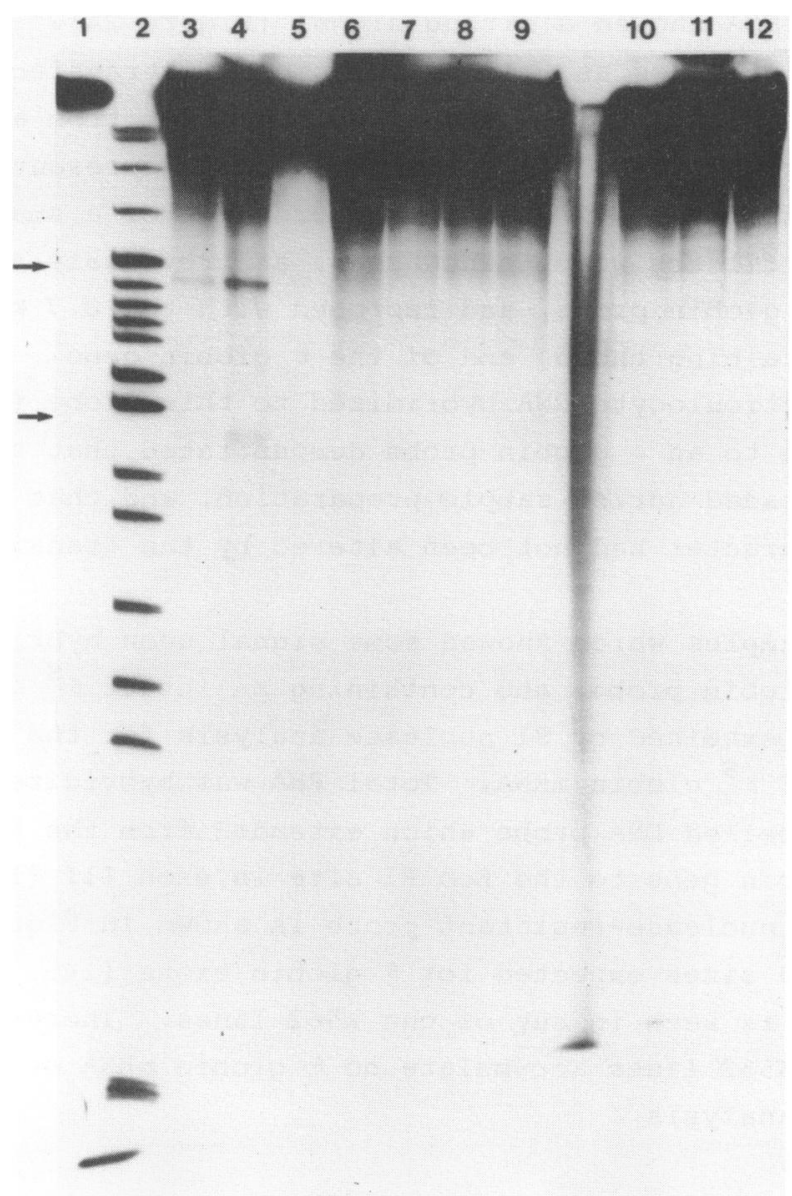

Figure 3:

SI nuclease analysis of K562 RNA:

$4.4 \times 10^{5} \mathrm{cpm}$ of uniformly labelled probe was hybridized to total RNA, digested with SI nuclease, and separated on an 88 acrylamide/508 urea gel. The upper arrow indicates the position of the exon 2 band (220 basepairs [bp]), and the lower arrow indicates the position of the exon 1 band (145 bp). Lanes: 1) probe; 2) Marker - pBR 322 Hpa II; 3) $10 \mathrm{ng}$ reticulocyte RNA; 4) $50 \mathrm{ng}$ reticulocyte RNA; 5) $50 \mathrm{\mu g}$ HeLa RNA; 6) $50 \mathrm{\mu g}$ uninduced $\mathrm{K562-2;7)} 50 \mathrm{\mu g}$ induced $\mathrm{K} 562 ; 8-12) \quad 50 \mathrm{~kg}$ RNA from 5 induced, transformed K562 lines.

negative control. Recovery of RNA from different samples was quite comparable by measurements of optical density and $28 \mathrm{~S}$ and 18 RNAs by Northern blots.

When these samples were probed with the $1.8 \mathrm{~kb}$ Bam $\mathrm{HI}$ fragment containing part of the $\beta$ globin gene, only the 
reticulocyte RNA showed a strong signal (Figure 2A). Several of the transfected lines as well as occasional untransfected lines showed a weak signal. The signal, when present from a given RNA sample, was reproducible. This signal could represent cross hybridization to $\delta \mathrm{mRNA}$ or the presence of a small amount of B mRNA. The filters were then washed, as previously described, to remove the $B$ globin probe, and reprobed with the $0.7 \mathrm{~kb}$ Bam $\mathrm{HI}$ fragment containing the $5^{\prime}$ end of the $\varepsilon$ globin gene. All samples except the reticulocyte RNA hybridized to this probe (Figure 2B). Hybridization to an $\varepsilon$ globin probe demonstrated that the RNA had not been degraded during sample preparation, and that the cells' erythroid character had not been altered by the transformation procedure.

Those samples which showed some signal upon hybridization with the $\beta$ globin probe, and containing an intact ${ }^{S} \mathrm{~S}$ gene (see below), were examined by $S I$ nuclease analysis for the presence of low levels of $\beta^{S}$ globin mRNA. Total RNA was hybridized to a uniformly labelled DNA probe which extended from the Bal I site $5^{\prime}$ to the $B$ globin gene to the Eco RI site in exon III (15). The resulting $S l$ nuclease-resistant probe is shown in Figure 3 . No signal of the sizes expected for $B$ globin exons $(145,225$, and 49 nucleotides) is seen in any of the $\mathrm{K} 562$ lanes. Therefore, these transformed $\mathrm{K} 562$ lines accumulate no $\beta$ globin mRNA detectable by Sl nuclease analysis.

DNA analysis:

Southern blotting analysis was done to determine which transformed $\mathrm{K} 562$ lines contained an intact $\beta^{S}$ globin gene. To distinguish the exogenous $\beta^{S}$ globin gene from the endogenous $\beta$ globin gene, Hinc II, a restriction enzyme that cleaves within the ${ }_{B} S$ globin insert and in flanking plasmid sequences in psv2neo, was used to detect a unique sized fragment which contains the entire ${ }_{B} S$ globin gene. Because one of the Hinc II restriction sites is within plasmid sequences, the $B^{S}$ globin containing fragment differs in size from the fragment containing the endogenous $B$ globin gene. A $3.3 \mathrm{~kb} \mathrm{~B}$ globin gene Hinc II fragment is produced from psv2neo- $S$, and a $5.4 \mathrm{~kb}$ fragment from the endogenous $B$ gene (Figure 1). The $3.3 \mathrm{~kb}$ Hinc II fragment includes $0.8 \mathrm{~kb}$ of $5^{\prime}$ flanking globin sequences and $0.55 \mathrm{~kb}$ of $3^{\circ}$ flanking globin 


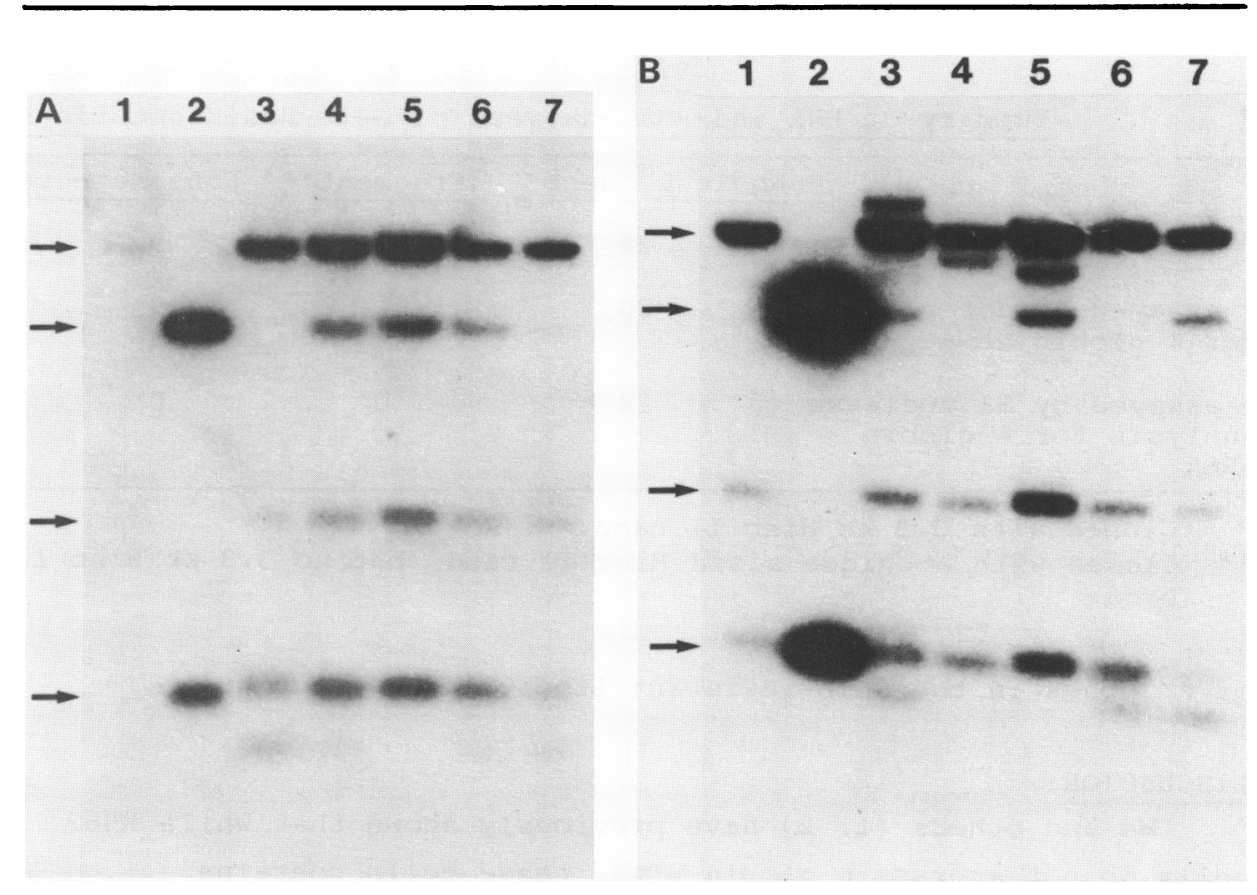

Figure 4:

Restriction analysis of G418-resistant K562 lines:

$5 \mathrm{\mu g}$ genomic DNA, Or $50 \mathrm{pg}$ plasmid DNA, was digested with Hinc II, separated on a 0.88 agarose gel, and transferred to nitrocellulose.

The hybridization probe was the nick translated $1.8 \mathrm{~kb}$ Bam HI B globin gene fragment $\left(5 \times 10^{\circ} \mathrm{cpm} / \mu \mathrm{g}\right)$. The arrows indicate, from top to bottom: the $5.4 \mathrm{~kb}$ fragment containing the engogenous $B$ globin gene; the $3.3 \mathrm{~kb}$ fragment containing the exogenous $B$ globin gene; the $1.3 \mathrm{~kb}$ o globin gene fragment which cross hybridizes with the $B$ globin probe; and the $607 \mathrm{bg}$ fragment 5 ' to the $B$ globin gene. Lanes: 1) K562-2; 2) psV2neo-B ; 3-7A) G418-resistant lines; 3-7B) more G418-resistant lines.

sequences. The $1.8 \mathrm{~kb}$ Bam HI fragment was used as probe. Figure 4 shows the results of some of these analyses.

In 24 of 36 lines, a $3.3 \mathrm{~kb}$ Hinc II band is present showing that an intact $B^{S}$ globin gene is present. Bands larger and smaller than the endogenous $5.4 \mathrm{~kb}$ band indicate the presence of integrated pSv2neo- $B$ sequences (Table 1 ). The number of $B S$ globin gene copies can be estimated by comparing the intensities of the endogenous and exogenous gene bands. The transformed lines have 2-5 copies of the $\beta^{S}$ globin gene ( $K 562$ is pseudo triploid) (16). The enzyme Mst II which cleaves the normal $B$ gene at codon 6, but not the $B^{S}$ gene, was also used to demonstrate the presence 
TABLE 1

Summary of DNA and RNA Analyses of G418-Resistant Lines

\begin{tabular}{|c|c|c|c|}
\hline & 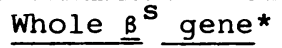 & Fragment** & None detected \\
\hline \# 1 ines total & 24 & 3 & 9 \\
\hline $\begin{array}{l}\text { \# assayed by dot blots } \\
\text { for B globin mRNA }\end{array}$ & 20 & 1 & 9 \\
\hline $\begin{array}{l}\text { \# assayed by } S I \text { nuclease } \\
\text { analysis for } B \text { globin } \\
\text { mRNA }\end{array}$ & 12 & 0 & 0 \\
\hline
\end{tabular}

* Clones with $3.3 \mathrm{~kb}$ Hinc II band.

** Clones with a unique sized Hinc II band, but no $3.3 \mathrm{~kb}$ Hinc II band.

of ${ }^{S}$ genes in the G418-resistant lines (data not shown).

\section{DISCUSSION :}

We and others $(1,2)$ have previously shown that while K562 cells do not express $B$ globin mRNA, these cells contains functional $B$ globin genes; these genes can be cloned and lead to the production of normal amounts of stable $B$ mRNA when transfected and expressed in tissue culture $(1,2)$. These results are consistent with the presence of trans acting factors in K562 cells which prevent the expression of $\beta$ globin genes in these cells. To further explore this problem, we stably transfected K562 cells with human $B^{S}$ globin genes. In this paper, we report that while intact $\beta^{\mathrm{S}}$ globin genes are stably integrated into 24 of 36 G418-resistant K562 lines, they are not expressed in any of these lines. This is in contrast to results obtained when $\varepsilon$ globin genes were stably integrated into a $\mathrm{K} 562$ strain which produces very low amounts of $\varepsilon$ globin mRNA. In that case, 10 of 11 transformed lines produced $\varepsilon$ globin mRNA (3). These results further support the hypothesis that the lack of $B$ globin gene transcription in $\mathrm{K} 562$ cells is due to a trans acting effect, either the presence of a negative regulatory factor or the absence of a positive regulatory factor. The results also indicate that the repression of $\beta$ globin genes does not require a large amount of flanking sequence since lines with an intact $3.3 \mathrm{~kb}$ Hinc II 
fragment with only $0.8-2.2 \mathrm{~kb} 5^{\prime}$ to the $B$ gene are negative for $B$ globin gene expression.

Gene transfer and cell fusion experiments have also suggested that trans acting factors control globin expression in both mouse and human erythroleukemia cells. Wright et al (13) have shown that when cosmids containing both the fetal and adult $B$ globin genes are transfected into MELC only the adult genes are expressed. In cell fusion experiments involving MELC and non-erythroid cells, the $B$ globin gene of human non-erythroid cell lines is inducible after cell fusion with $\operatorname{MELC}(17,18)$, but the $r$ globin gene is not (18). However, not all MELC fusions result in globin gene expression (19, 20), and the globin gene expression appears to be influenced by other incoming chromosomes (21, 22). In experiments involving fusion between MELC and human erythroid cells (K562 or human erythroleukemia), the MELC environment again alters the expression pattern of the foreign globin genes ( 23 , 24). Gene transfer experiments with other gene systems have shown that trans acting factors mediate gene expression in differentiated cells. Storb et al (25) have shown that a cloned immunoglobulin $K$ gene is expressed in a completely tissue-specific manner in six of six transgenic mice.

Two examples of tissue-specific control involving the 5 ' region of the $B$ globin gene are known. Changes in the DNAase hypersensitive sites $5^{\prime}$ to the globin genes are associated with induction of the gene $(27,28)$. Gilmour et al describe a negative regulatory sequence $5^{\prime}$ to the mouse $\beta^{\text {major }} \overline{\text { globin gene which acts }}$ on the mouse $\beta$ globin or human $\varepsilon$ globin promoters, but not on the HSV-l tk gene promoter in mouse and hamster fibroblasts (29). However, cell- or stage-specific gene expression positively controlled by the $5^{\prime}$ flank of globin genes has not been demonstrated as it has been for insulin and chymotrypsin genes (30). Indeed, recent results indicate that the sequences responsible for the appropriate expression of $B$ globin genes in erythroid cells may lie within or $3^{\prime}$ to the globin gene as well as in the $5^{\prime}$ flanking region $(31,32)$.

The use of gene transfer experiments with different human erythroid cell lines may permit the identification of those sequences which signal that a gene is a globin gene of the correct 
developmental stage, and which enable it to respond to an inducer and also may allow the isolation of factors which exert an effect on the globin gene sequences.

\section{ACKNOWLEDGMENTS :}

We wish to thank Una T. Collins for preparing this manuscript. This work is supported by grants from the National Institutes of Health - AM-25274; KY was a postdoctoral fellow on AM-07373; MD-P is a predoctoral fellow on GM-07088.

${ }^{*}$ To whom correspondence should be addressed at Columbia University, Hammer Health Sciences Center, Room 1602, 701 West 168th Street, New York, NY 10032, USA

\section{REFERENCES :}

1. Donovan-Peluso, M., Young, K., Dobkin, C., and Bank, A. (1984) Mol. Cell. Biol. 4, 2553-2560.

2. Fordis, C. M., Anagnou, N. P., Dean, A., Nienhuis, A. W., and Schechter, A. N. (1984) Proc. Natl. Acad. Sci. 81, 4485-4489.

3. Young, K., Donovan-Peluso, M., Bloom, K., Allan, M., Paul, J., and Bank, A. (1984) Proc. Natl. Acad. Sci. 81, 5315-5320.

4. Lozzio, C. B. and Lozzio, B. B. (1975) Blood 45, 321-330.

5. Rutherford, T., Clegg, J. B., Higgs, D. R., Jones, R. W., Thompson, J., and Weatherall, D. J. (1981) Proc. Natl. Acad. Sci. 78, 348-352.

6. Benz, E. J., Murnane, M. J., Tonkonow, B. L., Berman, B. W., Mazur, E. M., Cavallesco, C., Jenko, T., Snyder, E. L., Forget, B. G., and Hoffman, R. (1980) Proc. Nat1. Acad. Sci. 77, 3509-3513.

7. Marks, P. A., and Rifkind, R. A. (1978) Ann. Rev. Biochem. 47, 419-430.

8. Dean, A., Ley, T. J., Humphries, R. K., Fordis, M., and Schechter, A. N. (1983) Proc. Natl. Acad. Sci. 80, 5515-5519.

9. Miller, C., Young, K., Dumenil, D., Alter, B. P., Schofield, J. M., and Bank, A. (1984) Blood 63, 195-200.

10. Charnay, P., and Maniatis, T. (1983) Science 220, 1281-1283.

11. Chao, M. V., Mellon, P., Charnay, P., Maniatis, T., and Axel, R. (1983) Cell 32, 483-493.

12. Spandidos, D. A., and Paul, J. (1982) EMBO J. 1, 15-20.

13. Wright, S., deBoer, E., Grosveld, F. B., and Flavell, R. A. (1983) Nature 305, 333-336.

14. Southern, P. J. and Berg, P. (1982) J. Mol. Appl. Genet. 1, 327-347.

15. Ley, T. J., Anagnou, N. P., Pepe, G., and Nienhuis, A. W. (1982) Proc. Natl. Acad. Sci. 79, 4775-4779.

16. Klein, E., Ben-Bassat, H., Neumann, H., Ralph, P., Zeuthan, J., Polliack, A., and Vanky, F. (1976) Int. J. Cancer 18, $421-425$.

17. Pyati, J., Kucherlapati, R. S., and Skoultchi, A. J. (1980) Proc. Natl. Acad. Sci. 77, 3435-3439.

18. Willing, M. C., Nienhuis, A. W., and Anderson, W. F. (1979) Nature 277, 534-538. 
19. Deisseroth, A., Buck, R., Piccianno, D., Minna, J., Anderson, W. F., and Nienhuis, A. W. (1975) Proc. Natl. Acad. Sci. 72, 1102-1106.

20. Conscience, J.-F., Ruddle, F. H., Skoultchi, A., and Darlington, G. J. (1977) Somatic Cell. Genet. 3, 157-172.

21. Benoff, S., Bruce, S. A., and Skoultchi, A. (1978) Proc. Natl. Acad. Sci. 75, 4354-4358.

22. Benoff, S., and Skoultchi, A. (1978) Cell 12, 263-274.

23. Papayannopoulou, T., Lindsley, D., Kurachi, S., Deisseroth, A., Najfeldt, V., and Stamatoyannopoulos, G. (1984) Clin. Res. 32, 493a (Abstract).

24. Anagnou, N., Lim, E., Wang, A., Yuan, T., Helder, J., Chesbro, B., Colbert, D., and Deisseroth, A. (1983) Clin. Res. 31, 477a (Abstract).

25. Storb, U., O'Brien, R., McMullen, M., Gollahon, K., and Brinster, R. (1984) Nature 310, 238-241.

26. Busslinger, M., Hurst, J., and Flavell, R. A. (1983) Cell 34, 197-206.

27. Weisbrod, S. (1982) Nature 297, 289-295.

28. Miller, D. M., Turner, P., Nienhuis, A. W., Axelrod, D. E., and Gopalakrishnan, T. V. (1978) Cell 14, 511-524.

29. Gilmour, R. S., Spandidos, D. A., Yass, J. K., Gow, J. W., and Paul, J. (1984) EMBO J. 3, 1263-1272.

30. Walker, M. D., Edlund, T., Boulet, A. M., and Rutter, W. S. (1983) Nature 306, 557-561.

31. Charnay, P., Treisman, R., Mellon, P., Chao, M., Axel, R., and Maniatis, T. (1984) Cell 38, 251-263.

32. Wright, S., Rosenthal, A., Flavell, R., and Grosveld, F. (1984) Cell 38, 265-273. 